\title{
David Ives' Time Flies and/as Parody
}

\section{Leila Hajjari}

\author{
M.A., Persian Gulf University of Bushehr, Bushehr, Iran; Email: Ihajjari@gmail.com
}

Hossein Aliakbari Harehdasht

Assistant Prof., Persian Gulf University of Bushehr, Bushehr, Iran; Email: haliakbari@pgu.ac.ir

\author{
Doi:10.5901/mjss.2015.v6n5s2p158
}

\section{Abstract}

Parody as a type of literary creation can be seen from two perspectives: one is its formal meaning in its lexical and linguistic context, and the other is its social and/or cultural functions. When seen in the shade of these two (formal and functional) contexts simultaneously, the meaning it gets becomes innumerable and serves as a deconstructive force to challenge the desire for closure. The study of a literary text from this perspective finds an interesting and limitless scope. Taking David Ives' short play, Time Flies, as an example, we try to expound on and reveal the true potentiality of parody along with the critical reading of the play itself. In fact, our reading demonstrates the critical power of parody especially in a postmodern context. Going through many postmodern critics, we try to show that parody is the best means of representing postmodern condition, the incredulity to metanarratives in literature and/or art.

Keywords: Parody, Time Flies, typology, function, postmodern

\section{Introduction}

Genre, the Latin word for type, may either be used for literary typological or taxonomic purposes or be extended to the question of identity in a more social, cultural, or even commercial arenas. The scholarly field known as literary genre studies is one of the approaches that concerns itself with the typology of the literary text or texts in order to discover the structural elements that are combined in telling a story ("Genre Studies" Wikipedia). The hegemonic naming of types and kinds has thus been deployed in the field of literary genre studies in order to make meaning and/or structure accessible. Therefore, it is not very odd to see people claim that David Ives' short play, Time Flies, is parodic. At the end of a short note by Madstage Theatre announcing the performance date and time of the play, Time Flies, in the year 2003, it reads, 'Listed by New York Magazine as one of the ' 100 Smartest New Yorkers,' David Ives is a master of combining parody [emphasis added], witty dialogue and theatricality to create gut-wrenching laughter" ("Time Flies").

The generic reference to David Ives' play as parody seems a little abrupt especially in such a short announcement. Their description must have been induced by the fact that it entertains the audience by a playful mimicry and/or caricature of human life deploying two insects as the central characters. The action is funny, the speech hilarious and the humorous atmosphere is set upon the play from the very beginning. However, the question is: Do the fun and playfulness of the mimicry observed in the play give it the legitimacy of being called a parody? To answer this question is the main objective of our study. Accordingly, we will first present the diversity of the meaning of parody; then, we will elaborate on its function and examine the putative play.

The reason behind our interest in the typological (genre) study of parody and Time Flies is that there are many different outlooks towards the meaning as well as structure of parody; it is hard to come up with an inclusive definition. Designation of a play like Time Flies as parodic needs a lot of care and rhetorical knowledge. Literary critics, classic, modern or postmodern, have referred to a range of similarities between parody and other literary forms; the forms like travesty, burlesque, mock-heroism, spoof, meta-fiction, and pastiche can only by subtle nuances be differentiated from parody. These nuances are disregarded by those who find parody and the other forms generically identical. They are, however, taken seriously into consideration by those who would like to separate parody's arena from that of the other types. Thus, the side one takes in dealing with parody might make all the differences especially when they are involved in a typological analysis of a work to determine if it is a parody, pastiche, travesty, burlesque, etc. 


\title{
2. Typological Study of Parody
}

M. H. Abrams (2012), in his A Glossary of Literary Terms, considers parody as a subdivision of high burlesque and proclaims that

A parody imitates the serious manner and characteristic features of a particular literary work, or the distinctive style of particular typical stylistic and other features of a serious literary genre, and deflates the original by applying the imitation to a lowly or comically inappropriate subject. (38)

J. A. Cudden (1979), however, believes that parody is "a kind of satirical mimicry. As a branch of satire . . . its purpose may be corrective as well as derisive" (483). Jonathan Culler (1975), on the other hand, sets a condition for parody's distinction from burlesque foregrounding its relation to the original text when he writes:

If it is to avoid burlesque, parody must capture something of the spirit of the original as well as imitate its formal devices and produce through slight variation-usually of lexical items-a distance between the vraisemblance of the original and its own. (153)

He continues to find similarities between irony and parody. However, his discussion comes to signify that they differ in their formal effects because "irony always offers the possibility of misunderstanding" (154) implying that parody can be comprehended very much literally and does not invite ambivalence or ambiguity.

The controversial attitudes towards parody observed above assume a higher pitch among postmodern critics. Fredric Jameson (2000), for instance, refutes the possibility of "recourse to nature, or the past, or 'high' culture" in the contemporary culture because, he believes, the post-industrial, late capitalist, consumer (to use some his terms) society lacks cultural hierarchies. He asserts that the new cultural practices are characterized by pastiche which "[is] to be distinguished from parody by the absence of any critical distance from the ur-text". He insists that

\begin{abstract}
In such a situation, the critical force carried by parody . . . has been replaced by pastiche, in which artists, architects and writers can endlessly allude to other styles in an interminable recycling which mirrors the unending commodity circulation of an absolutely extensive capitalism. (Dentith 155)
\end{abstract}

Jameson's emphasis on "interminable recycling" undermines the idea of closure. Meaning thus fails to pause and is disseminated (to use Derrida's term) within innumerable insatiable contexts.

Linda Hutcheon finds the parody and pastiche identical in that they function similarly to both "affirm and subvert the conditions of history: history is exposed as a contingent narrative, while the will to historicizing is confirmed" (Encyclopedia of Postmodernism, 2001, 275). She disdains "modernist pretensions to artistic independence" and asserts the necessity of "'intertextual' nature of the production of meaning" in the postmodern era (95-96).

Terry Eaglton, however, echoes the same zeal and aptitude seen in Jameson only to chastise the postmodern culture which, to him, as it did to Jameson, sounds empty and depthless. He postulates that

The aesthetics of postmodernism is a dark parody of such anti-representationalism: if art no longer reflects, it is not because it seeks to change the world rather than mimic it, but because there is in truth nothing there to be reflected, no reality which is not itself already image, spectacle, simulacrum, gratuitous fiction. (David Lodge, 2000, 363)

He uses Baudrillard's idea of simulacrum to emphasize the impossibility of creating any serious work of art. He insists that the grounds for such creations are missing in postmodern era. Therefore, the contemporary cultural practices have to resort to the past and wishfully imitate its content. To him, postmodernism itself becomes a parody of socialist utopia, the one "not as some remote telos . . .but, amazingly, as nothing less than the present itself" (362) which is lacking due to its replacement with virtual reality (or unreality) of images.

John Docker (2000), meanwhile, emphasizes "the pervasiveness of parody in contemporary mass-cultural forms" and sees it "as acting in closely comparable ways to the carnival forms of renaissance" (Dentith 157), emanating Jameson and Eaglton's ideas about parody believing that "[p]ostmodern artistic practice" originates from "the rich history of popular-cultural forms, [and is] understood in Bakhtinian terms" (Dentith 158). Thus he emphasizes the carnivalesque as well as dialogic nature of parody.

Parody's usefulness here resembles that of mimicry (see Cudden above) since mimicry, as Hawthorn (1998) postulates, likewise "involves the subversive potential contained in the forced and (often overtly) half-hearted adoption of the style or conventions of a DOMINANT authority-whether national-CULTURAL or GENDER-political." He believes that 
"the concept also carries with it some of the associations of 'poking fun'-a sort of body-language equivalent of parody" (206).

Margaret Rose (2000) emphasizes meta-fictional aspect of parody asserting that "parodying one text (or kind of text), the parody text holds up a mirror to its own fictional practices, so that it is at once a fiction and a fiction about fiction." She continues to say that "while apparently being destructive, parody texts actually create new fictions out of their own parodic procedures" (Dentith 15).

Finally, Dentith (2000), in his book, Parody, which is a cornucopia of genealogical information about parody and an indispensable help to the present study, relates parody and allusion together believing that parody is an evaluative intertexual allusion. Followings are some of the definitions he provides:

\begin{abstract}
-"parody involves the imitation and transformation [italics are mine both here and in the three following quotations] of another's words. That might also pass as an account of language use more generally, for language is not ones' own, but always comes to each speaker from another, to be imitated and transformed ...." (3).

-"parody is one of the many forms of intertexual allusions out of which texts are produced" (6).

-"parody forms part of a range of cultural practices, which allude, with deliberate evaluative intonation, to precursor texts" (6).

-"Parody includes any cultural practice which provides a relatively polemical allusive imitation of another cultural production or practice" (9).
\end{abstract}

As we see, Dentith's definitions are general and inclusive. He looks at parody not as a single exclusive entity but a spectrum that contains "the myriad conscious ways in which texts are alluded to or cited in other texts" (5), a spectrum that includes all kinds of imitation such as pastiche, mock-heroic, burlesque, travesty, satire, carnival, meta-fiction, as well as parody itself (6). What is ultimately important to notice here is the fact that parody is deliberate and evaluative. Dentith emphasizes the polemic aspect of parody and implies that its polemically evaluative role counts more than any pigeonholing classifications.

\title{
3. Functional Aspects of Parody
}

Besides its multiple lexical or semantic meanings, as the definitions showed, parody is also capable of performing various critical roles depending on the context it is employed.

When dealing with parody as a polemic cultural practice, we should always remember that there is an absent presence (to use Derrida's terms) at its core; parody presents an origin which is absent, that resides in the past, hence its imitation from the precursor text(s). This past-ness of the past must not be confused with the far past though this always remains a possibility. It can be an immediate past. Nonetheless, there is always something prior to parody, there is always a pre-text (in its double meanings).

Parody makes this pre-text present, eventually leading to the presence of the past in the present time. However, we should emphasize the polemic aspect of parody and refer to the fact that the past re-historicized by parody is not an intact past. It is, on the contrary, a past that is distorted and/or subverted through the parody's inflective impact.

Foucault's (2004) idea of Genealogy, therefore, shares a lot with what parody does to the past. "What is found at the historical beginning of things," he writes, "is not the inviolable identity of their origin; . . . The lofty origin is no more than 'a metaphysical extension ... [that] always precedes the fall" (74). What is implied here is that the past lofty origin is doomed to fall. Henceforth, Foucault's view is not nostalgic but critical. He is critical of precedent time and associates it with theogony, with gods who, as origin, preceded humanity. Through history and/or genealogy, he believes, we can learn "to laugh at the solemnities of the origin (74) . . [because] [g]enealogy [to Foucault] is history in the form of a concerted carnival" (83). Foucault's idea of genealogy proves that history and parody can be identical in the role they perform; that parody has the potential of doing the same thing to its preceding text-god. It helps us to laugh at the solemnity of the preceding 'original' text. Thus its lofty presence is pushed back and its representational artificiality is unveiled.

Unlike Foucault, however, Jameson's views of history and the origin, sound quite nostalgic. He "sees the return of the older cultural styles not as the return of history" since, to him, history proper, after being remade "in the empty image of late capitalism," has become simply an image, a simulacrum, "a copy that does not have an original" (Encyclopedia of Postmodernism, 2001, 275). In fact, one of the dominant features of Postmodernism, to Jameson, is the "consequent weakening of historicity" (193) which is caused by the prevalence of image or simulacrum, the lethal potion that causes the "death of the subject itself-[and heralds] the end of the autonomous bourgeois monad or ego or individual . . . the decentering of that formerly subject or psyche" (193). 
Hutcheon (2000) resides somewhere between Jameson and Foucault taking a moderate position. She sees parody as an "ironic . . . revisiting of the past ... of both art and history" (99). She sees parody fundamentally ironic and polemical, not nostalgic or antiquarian. As she reaffirms, "It 'de-doxifies' [sic] our assumptions about our representations of the past" (94).

As we can observe, the controversial views of parody trespass its mere lexical nomenclature and reach the domain of its pragmatic role(s) as well. What follows provides more examples of such controversy among the critics who deal with parody.

Jonathan Culler (1975), for instance, observes the naturalizing power of parody in reading history. He writes: "In calling something a parody we are specifying how it should be read, freeing ourselves from the demands of poetic seriousness, and making the curious features of the parody intelligible" (152). He denies the seriousness of parody and believes that it alienates us from the ur-text which makes a more literal interpretive process possible. This is accomplished, he says, because parody due to its imitative nature makes its model explicit implicitly denying it being read as a serious statement of feelings about one type of vraisemblance used to enforce metaphorical readings of poems (153).

Robert Phiddian (2000), on the contrary, believes that "parody throws some of the very fundamentals of writing into doubt." (Dentith 15). He follows Roland Barthes' notion of 'death of the author' and Derrida's 'writing under erasure to make the "densely intertexual nature of all writing ... transparent so that its 'authorship' becomes problematic" (15). Writing under erasure, therefore, becomes a metaphor for parody's action. He writes:

Parodic erasure disfigures its pre-texts in variety of ways that seek to guide our re-evaluation or re-figuration of them. It is dialogical and suggestive as well as negatively deconstructive, for it (at least poetically) can achieve controlled and met-fictional commentary as well as purely arbitrary problematization. (qut. in Dentith 15-16)

This dual function of parody is referred to as double coding by critics like Hutcheon. She believes that "As form of ironic representation, parody is doubly coded in political terms: it both legitimizes and subverts that which it parodies" $(2000,97)$. Hutcheon $(2000)$ emphasizes parody's self-conscious approach to postmodern culture and believes that it can reveal how ideologies and/or authorities are made legitimized throughout history (97). Henceforth, parody takes a more serious role opposite what Culler was trying to suggest (see above).

This self-consciousness is the very distinguishing feature Charles Jencks (1992) generally ascribes to his coinage, the Post-Avant-Garde. Jencks distinguishes the new avant-gardism from its predecessors by saying that

The great strength of the Post-Avant-Garde is to recognize what its predecessors couldn't admit to themselves; that it is a small part of the powerful middle class which is indefatigably transforming the world in ways that are simultaneously destructive and constructive. It doesn't seek to hide this self-knowledge or pretend it can lead the working class or overcome the contradictions between life and art . . . and in this modest self-recognition lies its particular kind of authenticity. (224)

We can see similar aspirations for authenticity and modesty in parody as well. Actually, I would like to make this bold proposition that parody is the voice of post-avant-garde cultural practices and the genre that speaks the spirit of this age, hence its pervasiveness in the postmodern era.

The Googling research done for a decade's (1995-2005) articles and books written on and about irony and parody reveals that more than $3,220,000$ results exist for parody which gives it the second rank closely below irony with $3,980,000$ results as the first. As Hutcheon (2008) consents "That range says much about the ubiquity of both in Western culture - across the centuries, across media, and across cultures" (7). Parody's pervasive presence, therefore, demands a real attention and a resilient pursuit of its conduct both in arts and in the now dominant popular culture.

Since no definition or "classification can ever hope to be securely held in place" (Dentith, 2000, 6), we have so far incorporated into the realm of parody all the features that can help orchestrate its function better and reveal the raison d'etre of a parodic construction.

\section{Time Flies and/as Parody}

David Ives' Time Flies can be matched specifically with all the ideas and definitions mentioned above the result of which will be varied evaluations of the play's function for/against history or historicity of meaning.

As went before, according to Dentith, a work should possess at least three features to become a parody; it must be playful, imitative and evaluative. The first element that makes the play amusingly funny is the disfiguring and transplanting 
human condition into the realm of insects. Identification of man with non-humans and bestowing his roles to other creatures create an atmosphere of relief and decreases tension. This atmosphere is indispensable to parody; it keeps the vivacity of fun which is most often killed in satire or other forms of writing. Identifying man's desires with those of the two tiny insects (that live only for one day) both exaggerates his mortality and preserves his detached amusement of cherishing a much longer life in comparison with inferior creatures.

The fun is also created in the linguistic level of the play when human speech is articulated by the two wanton insects. May's "Thank you for flying me home" (1063) parodically imitates the common speech of the dating couples when one walks the other home. Here are some more examples:

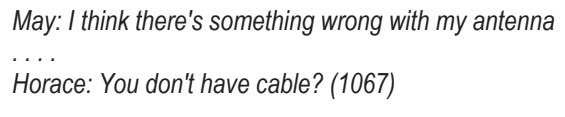

May: I think it was larva at the first sight. (1069)

May: Oh yes. Yes. Just like that. Keep going. Harder. Rub harder. (1069)

May: Oh, Horace, I had such plans. I had such wonderful plans. I wanted to see Paris. (1072)

The fun in these speeches can shake anyone's entrails with laughter.

The second element is the use of pun which gives the speech utmost associative power and keeps the passage open for the audience to commute between the double spaces of the play moving from the human life into that of insects and return back as instantaneously as possible. As an example, we would like to refer to the title of the play which both refers to the mayflies that are paradoxically 'time' flies, that is, they live a very short life, hence their order, Ephemeroptera, "from the Greek ephemeros='short-lived,' ptera='wing"' ("Mayfly"), and reminds us of a well-known English saying implying the precious value of time to human beings. There are other examples of pun in the play which perform the same task.

Ives' parody of the contemporary music is also achieved through pun. The part of the play that testifies to this parodic depiction is as follows:

May: Care for some music? I've got The Beetles. The Byrds, The Crickets...

Horace: I love the Crickets.

May: Well so do I . . . (She kicks a large, insect-shaped coffee table, and we hear the buzz of crickets.) (1064)

The pun used here and other places in the story intensifies the effects and magnifies the fun that we expect to receive from a good parody. The pop or rock music clubs named by May did really exist in the seventies or later. However, the names refer to the real insects and animals as well. This infatuation with the animal or insect names reveals man's diminished sense of humanity and his increased inclination to identify with the lesser beings. It is in the contemporary cultural practices that heroes like Catwoman, Batman or Spiderman are nourished and mythologized.

Imitation is the second major element in determining the structure of parody. The pre-text that Time Flies imitates, however, is not a specific artifact in literature; the text (in its Barthian meaning) that the play imitates is, in fact, the conventions of a whole period in the western literature. It imitates the conventions of beast fable of the Renaissance period in which animals "talk and act like human types they represent" (Abrams, 2012, 7). Another text associated with this play is the philosophy of Carpe diem (or seize the day) which was adopted by Renaissance humanists from the Roman philosopher, Horace (parodically re-presented by the male mayfly). Moreover, we can observe Ovidean romantic love parodied by the play, too.

The beast fable as we know aims at pedagogy and didacticism and the protagonists of such stories usually sum up the morale of the story in a short epigram at the end. The best example in the English literature is Chaucer's "Nun's Priest's Tale," the story of the fox and the rooster, Chanticleer.

Ives' parody subverts this tradition both by avoiding didacticism and by employing ephemeral insects instead of the so-called beasts and/or animals, hence extending the potentialities of such beastly imitations of man's action to the lowest realm of insects. If beast fables had this double enterprise both to teach and to parody human beings, Ives play parodies that parody and thus it turns against its own tradition.

Carpe diem as a philosophy of life found its way into Western literature through Horace. His Epicurean predilections found a lot of supporters among the metaphysical poets like Robert Herrick and Andrew Marvell (to name 
only two). His famous phrase, 'seize the day,' at least implies the possibility of taking pleasure in our short period of life. Following is an extract from Horace's Odes.

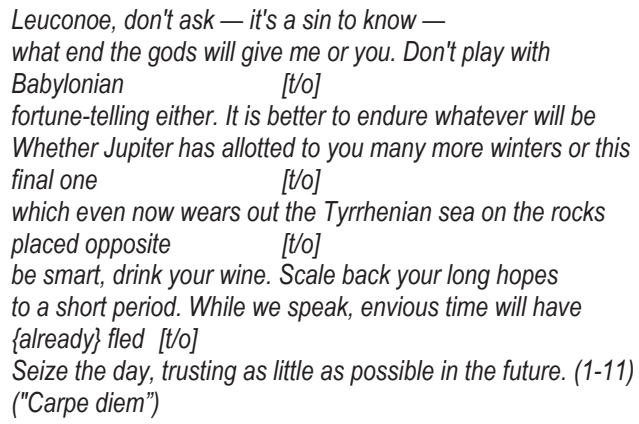

Horace is concerned about the passage of time and cannot but see life be lived with pleasure.

The play reproduces the dominant philosophical, cultural, and aesthetic issues of ancient Rome and early Renaissance and puts them into a new context the result of which is this double sense (double-coding) of nostalgia and absurdity, reproduction and deconstruction. The past is destroyed by the parodic approach and reconstructed to give it a new sense of reality; in the late capitalistic society of our time, when life and love have lost their sublime stature due to the machination and industrial materialism, one can either sigh and feel sorry for the absence of those values or just laugh it away negating their authenticity as real. The play itself can best exemplify how the parody provides such double coding.

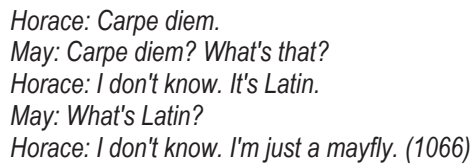

This extract besides giving credit to the play's meta-fictional aspect reveals the fact that Carpe diem as a philosophical practice or way of life does not make sense to the mayflies that are the parodied picture of postmodern man.

Mayflies only live for one day being unable to enjoy their time due to the interference of media with their private life. The overdose of information that is transmitted to them by T.V. set obliterates their pleasure and kills the appetite in them to enjoy life. The play actually parodies Horace's statements expressed in his Ars Poetica:

Think to yourself that every day is your last; the hour to which you do not look forward will come as a welcome surprise. As for me, when you want a good laugh, you will find me, in a fine state, fat and sleek, a true of [sic] hog of Epicurus' herd. (Books and Writers 2000)

Thus parody does not simply make us laugh at the past mortal values; it also breathes its self-consciousness into the audience to peep into the hollow swell of the contemporary cultural practices.

Ovidean love is prevalent in the sonnets written by Renaissance sonneteers such as Wyatt, Spencer and Sydney. They portray lovers who worship their beloveds as goddesses. The lovers had to sigh and suffer the agonies of love while the beloveds prove indifferent and uninterested. But this was the tradition and sonnets were meant to concretize these conventions like gilded monuments. David Ives' play imitates these conventions only to deflate their sublime enterprise, and the means by which it achieves its destructive power is laughter. In the following extract we can see how Horace as a lover distorts the romantic atmosphere of love poetry.

Horace: You know, May, we don't have much time, and really, we hardly know each other-but I'm going to say it. I think you're swell. I think you're divine. From your buggy eyes to the thick raspy hair on your legs to the intoxicating scent of your secretions.

May: Eeeuw.

Horace: Eeeuw? No. I say woof. And I say who cares if life is a swamp and we're just a couple of small bugs in a very small pond. I say live, May! I say . . . darn it . . . live!

May: But how? 
Horace: Well I don't know that ... . (1072)

This scene directly parodies the conventions of renaissance love poetry. Marlowe's "The passionate Shepherd to His Love," for example, promises of valleys, groves, hills, and fields.

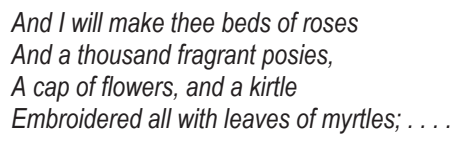

And I will make thee beds of roses

And a thousand fragrant posies,

A cap of flowers, and a kirtle

Embroidered all with leaves of myrtles; ....

A simple comparison between the ways Marlowe, for instance, invites her beloved into living and that of mayfly, Horace, shows how different the latter is from the former one. As we see, the crimson rosy panorama of that tradition is deranged by Horace's speech as a mayfly praising the odd qualities of its female partner. Horace's speech also echoes and parodies the lover in Marvell's "To his Coy Mistress":

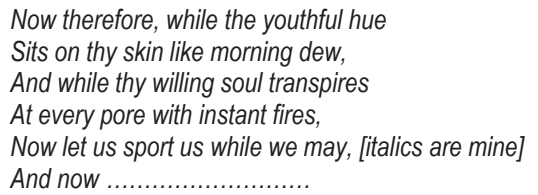

Horace's speech on one hand and the eventual laughter caused by it on the other distorts the seriousness and authenticity that is felt in the poems written by such poets as Marvell, Marlowe, etc. Thus, the play does not parody just one specific text or ur-text as it is called; rather, it parodies the convention of love poetry or the philosophy of carpe diem in a time when they are not practicable any longer. Therefore, if there is laughter, it is, in a Pinteresque manner, laughter and chill at the same time.

In Jameson's view, this kind of deflation of older human values gives evidence to the detrimental and anodyne aspect of parody, that is, parody becomes the means by which the supine contemporary culture thrives and the older sublime values are humiliated and crushed by laughter. However, as Lyotard (1984) argues, our postmodern condition is known by our "incredulity to metanarratives. This incredulity is undoubtedly a product of progress in the sciences: but that progress in turn presupposes it" (xxiv). The grand origin is doomed to fall and we cannot help but tragically laugh at its dissipating magnitude.

Parody can perform two tasks at the same time. It can both destroy and/or create thus becoming the site of interplay between opposing forces. Who uses parody and to what ends make all the differences.

David Ives has written a play whose polemic criticism and/or evaluation moves in two directions, towards both past and present. Its meta-fictional references divulge the representational aspect of both classical and postmodern art, media, and culture.

Media, for instance, is a site of cultural production and/or practice. But its supreme omnipresence devastates any hope for authentic un-artificial existence. David Attenborough's perpetual appearance and involvement in the life of the mayflies is just one miniature example. His first name is also reminiscent of the playwright's autobiographical presence in his play, especially because of his botanical knowledge.

David Attenborough's Voice:The mayfly has a lifespan of only one day-living just long enough to meet, mate, have offspring and die.

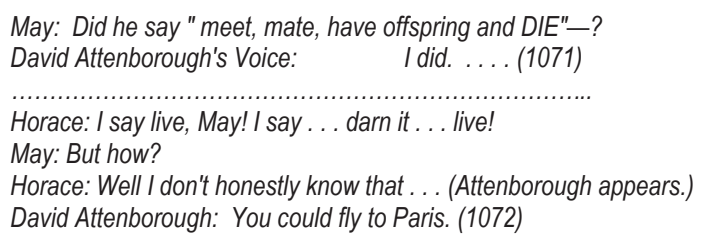




\section{Horace: What is carpe diem?}

David Attenborough: It means "bon voyage! (1072)

All these extracts foreground the vulnerability of postmodern privacy. It is the time when private and public has become identical. The pervasive presence of media and its prying into people's lives correspond to Baudrillard's idea of simulacrum, and to the invincibility of its poking presence. Thus, the play parodies, not only the past ideals, but also the destructiveness of the contemporary culture, its harassment of individuality and murdering of the self or ego by means of data bombardment and artificial intelligence. Quite ironically, the play focuses its attention not on the past representations per se, but on the post-avant-garde world. Its polemic evaluation addresses the present culture which lacks coherence and independence.

\section{Conclusion}

As we have observed through the points touched in this article, parody has a lot in common with other imitative forms. David Ives' play Time Flies acts as a parody in so far as it re-historicizes the past conventions only to direct its criticism towards the past as well as present and to destroy their autonomous legitimacy, to undermine the assumed truth of all narratives, grand or little. Mere typology of the play as parody may work as good commercial, but to know what parody does to its ur-text and how it does it are even more important. Since parody is never fixed in meaning and function, every text is potential of yielding to parodic anarchy. This study hopes to kindle the interest in the scholars to investigate more into the nature of parody in the postmodern art and literature.

\section{References}

Abrams, M. H. and Geoffrey Galt Harpham (2012). A Dictionary of Literary Terms. Ed. 10 $0^{\text {th }}$ ed. Boston: Thomas Wadsworth, Cengage Learning.

Books and Writers (2000). "Horace (65-8 B.C.) - Qintus Horatius Flaccus" 19 Aug. 2008. <http://www.kirjasto.sci.fi/horatius >.

"Carpe diem." [online] Wikipedia Contributors. Wikipedia, the Free Encyclopedia. 03 June 2015. Retrieved 03 June 2015. Available $<$ <ttp://en.wikipedia.org/w/index.php?title=Carpe_diem\&oldid=664436508>

Cudden, J. A (1979). A Dictionary of Literary Terms. Revised edition. England: Penguin Books.

Culler, Jonathan (1975). Structuralist Poetics: Structuralism, Linguistics and the Study of Literature. London: Routledge.

Dentith, Simon (2000). Parody. London and New York: Routledge.

Eagleton, Terry (2000). "Capitalism, Modernism and Postmodernism." Modern Criticism and Theory. Ed. David Lodge and Nigel Wood. $2^{\text {nd }}$ ed. United Kingdom: Longman.

Encyclopedia of Postmodernism (2001). Ed. Victor E. Taylor and Charles E. Winquist. London and New York: Routledge.

Foucault, Michel (2004). "Nietzsche, Genealogy, History." The Postmodern Reader. Ed. Michael Drolet. London and New York: Routledge.

Hawthorn, Jeremy (1998). A Glossary of Contemporary Literary Theory. 3rd ed. London: Arnold.

Hutcheon, Linda. [online] "Introduction: There will always be parody and Irony." 19 Aug. 2008.

Available <http://www.chass.utoronto.ca/french/litera/Revue_Texte/HUTCHEON.pdf>.

--- (2000). The Politics of Postmodernism. 2nd ed. London and New York: Routlede.

Ives, David (2006). Time Flies. Perrine's Literature: Structure, Sound, and Sense. Ed. Thomas R. Arp and Greg Johnson. 9th ed. Australia: Thomas Wadsworth.

Jameson, Fredric (2004). "Postmodernism, Or, the Cultural Logic of Late Capitalism." The Postmodern Reader. Ed. Michael Drolet. London and New York: Routledge.

Jencks, Charles (1992). "The Post-Avant-GArde." The Post-Modern Reader. Ed. Charles Jencks. London: Academy Edition.

Lyotard, Jean-Francois (1984). The Postmodern Condition: A Report on Knowledge. Translation from the French by Geoff Bennington and Brian Massumi. Forwarded by Fredric Jameson. Manchester: Manchester University Press.

Marlowe, Christopher (1993). "The Passionate Shepherd to His Love." The Norton Anthology of English Literature. Ed. M. H. Abrams. $6^{\text {th }}$ ed. Vol. 1. New York: W. W. Norton.

Marvell, Andrew (1993). "To His Coy Mistress." The Norton Anthology of English Literature. Ed. M. H. Abrams. 6th ed. Vol. 1. New York: W. W. Norton.

"Mayfly." [online] Wikipedia Contributors. Wikipedia, the Free Encyclopedia. 03 June2015. Retrieved 03 June 2015. Available <http:/l http://en.wikipedia.org/w/index.php?title=Mayfly\&oldid=665326018>.

"Time Flies." [online] Madstage. 03 June 2015 Available <http://www.madstage.com/oldshows/timeflies.html> 